\title{
KONTRIBUSI IRWAN ABDULLAH DALAM PENGEMBANGAN KEILMUAN ISLAM DI BIDANG MODERNISASI EKONOMI
}

\section{Muhammad Turhan Yani}

Fakultas IImu Sosial UNESA, Jalan Ketintang Surabaya 6023, HP. 081331020092, e-mail: myani51@yahoo.co.id

\section{Abstract}

From Irwan Abdullah's research, we can a very interesting phenomenon, namely, that Muslim traders in Jatinom (a small toum in Klaten, Central Java) can replace the position of Chinese traders and be successful traders until now. To know about their success, Inwan Abdullah conducted a research by studying three interrelated factors: (1) the role of religion in supporting trading activities; (2) trading as a part of broader economic system and as an important factor; and (3) the change of socialreligious factor and socialeconomic factor in Jatinom Muslim trader society that really cannot be separated from the local political context. Acconding to him, the political structure at the time when economy develops and its changes determine much the development of trading activities. The contributions of this research to Islamic science are: (1) giving the explanation of religion role in supporting human life activities, in this context, trading activities, both concerning with obvious economic behavior of the Muslim traders and the community's response to economic activities; (2) explaining that the role of religion in the process of thinking reformation can lead human behavior, that is, the traders' economic behavior, and can also influence the way people accept economic activities and trading as a part of their lives.

Key words: Muslim traders, the reformation of religious thinking, economic modernization

Ulul Albab, Vol. 10, No. 1, 2009 


\section{Pendahuluan}

Buku yang berjudul The Muslim Businissmen of Jatinom (Religious Reform and Economic Modernization in a Central Javanese Town) terbitan Universiteit Van Amsterdam tahun 1994 ini adalah sebuah karya ilmiah yang sangat berbobot di bidang modernisasi ekonomi dan kaitannya dengan pembaharuan pemikiran keagamaan. Buku ini merupakan hasil penelitian (disertasi doktot) Irwan Abdullah yang telah dilakukan (disertasi doktor) di Universitas Amsterdam Belanda.

Dalam disertasi yang diterbitkan menjadi buku ini, salah satu persoalan yang diteliti adalah tentang peran agama. Apakah agama mempunyai pengaruh kuat dalam pembentukan pilihan bisnis Muslim Jatinom, sosio politik dan struktur sosial-ekonomi di mana proses itu berlangsung (Abdullah, 1994: 26). Sebab di lain pihak, seperti di Barat sendiri belakangan ini memang diakui kajian tentang hubungan agama dan ekonomi sangatsedikit. Berikut di antara studi terkait dengan masalah ini (Harahap, 2005: 17).

Adam Smith dalam buku pertamanya sebenarnya menganggap unsur agama punya peran dalam bidang ekonomi. Dalam.hal ini agama disebut dengan istilah 'moral suasion'. Ia menyatakan bahwa aspek moral harus mewarnai dan berperan dalam ekonomi. Namun berikutnya dalam bukunya yang kedua yang lebih terkenal The Wealth of Nation aspek agama akhirnya hilang namun masih tetap ada fungsi yang hilang itu yang diganti dengan nama 'invisible hand' (Harahap, 2005: 17). Penelitian Irwan Abdullah ini sebagai salah satu counter atas pernyataan bahwa agama tidak memiliki peran penting untuk mendorong keberhasilan seseorang dalam berbisnis.

Dalam penelitian ini, Irwan Abdullah melakukan studi tentang keberadaan usahawan lokal. Menurutnya, studi tentang keberadaan usahawan lokal menjadi penting terutama untuk menggambarkan proses hubungan pembentukan penguasa ekonomi, dan juga untuk menganalisis faktor-faktor yang mendukung proses tersebut. Pemahaman terhadap masalah ini dapat memperdalam pengetahuan kita menyangkut karakteristik modernisasi ekonomi di berbagai tempat. Ini merupakan basis yang akan menjelaskan

Ulul Albab, Vol. 10, No. 1, 2009 
hubungan antara pembangunan ekonomi secara umum dan modernisasi ekonomi di tingkatan lokal. Oleh karena itu studi yang dilakukan Irwan Abdullah ini berhubungan dengan beberapa isu (Abdullah, 1994: 10).

Pertama, studi ini menjadi bagian dari debat berkelanjutan tentang hubungan antara usahawan kecil dan usahawan besar dan peran yang mereka mainkan dalam modernisasi ekonomi. Kedua, studi ini dihubungkan dengan diskusi tentang pengaruh faktor budaya dalam kemunculan para aktor ekonomi. Dalam hal menjelaskan kegagalan usahawan Jawa, banyak temuan studi seperti yang dikemukakan oleh cf. Alexander dan Alexander (1991) sebagai berikut: bahwa orang Jawa digambarkan sebagai orang yang pasif, bersikap tunduk, berorientasi konsumsi, pemborosan, tak tertarik mendapatkan keuntungan, tak mempunyai spirit berusaha, di dalam berpikir diilhami oleh magic-religius, dan tidak mampu menopang pekerjaan kecuali dalam pertanian (agrokultural) (Abdullah, 1994: 5).

Ketiga, studi ini menjadi bagian dari diskusi global tentang 'Hipotesis Susila Protestan' Weber. Dalam studinya ini, Irwan Abdullah berkonsentrasi pada salah satu aspek yang paling utama dari teori Weber, yakni 'Rasionalisasi'. Konsep ini digunakan sebagai suatu instrumen dalam menganalisis modernisasi ekonomi ketika diterapkan oleh pedagang Muslim Jatinom. Dalam hal ini, ia bermaksud meneliti pembentukan usahawan Muslim secara spesifik dalam konteks sosial dan ekonomi. Sejak awal, bagian penting dalam penelitian ini adalah proses rasionalisasi, dan menganalisis secara detail tentang peran agama (Abdullah, 1994: 5).

Dalam penelitian ini Irwan Abdullah mengemukakan bahwa etika religius pada banyak masyarakat Asia telah memainkan peran penting di dalam pembentukan masyarakat bisnis (Bellah, 1992; Eisenstadt, 1971, Hamilton, 1985). Dalam konteks Indonesia, banyak studi telah dilakukan di Pulau Jawa untuk meneliti kemajuan ekonomi dalam masyarakaat Islam, dalam hal ini yang paling utama seperti studi Alice Dewey (1962) tentang masyarakat perdagangan yang berasal dari pribumi, yang jaringan pemasarannya diselidiki di Mojokuto, studi Clifford Geerw (1963) tentang modernisasi ekonomi dalam hubungannya dengan pedagang Muslim, juga

Ulul Albab, Vol. 10, No. 1, 2009 
di Mojokuto (Abdullah, 1994: 26).

Dalam hal ini, Dewey dan Geertz dipandang sebagai pelopor riset dalam masyarakat perdagangan. Dewey menghubungkan sistem pasar pada konteks sosial-ekonomi yang lebih luas dengan menunjukkan saling keterhubungan yang fungsional antara pola perdagangan dan pola sosialekonomi masyarakat petani. Kedua-duanya menunjukkan pentingnya konteks sosial budaya pada ciri-ciri ekonomi Mojokuto. Dalam analisisnya, Geertz menghubungkan spirit berusaha pada ciri-ciri perubahan sosial di Mojokuto dengan tipe kepemimpinan ekonomi pada pedagang Muslim (Abdullah, 1994: 26).

Studi Geertz telah memberikan ilham pada penelitian lebih lanjut tentang hubungan antara pengembangan usaha dan pembaharuan Islam, seperti yang dilakukan oleh Lance Castles (1967) di Kudus and Huub de Jonge(1989) di Parindu, Madura. Mengikuti Geertz, Castles menghubungkan pengembangan usaha pada proses pemurnian Islam di Kudus. Sèmentara Huub de Jonge menunjukkan bahwa pembaharuan Islam telah merangsang penampilan kelompok bisnis lokal sebab terjadi perubahan pada nilai-nilai tradisional. Islam di Parindu dikembangkan menurut penguasa ekonomi dari kalangan pedagang Muslim. Beberapa studi lain mengenai Islam dan perdagangan dapat disebut sebagai berikut; Kuntowijiyo (1971), pada metal industriawan di Batur-Klaten, Mintsuo Nakamura (1976) pergerakan Muhammadiyah di Kotagede-Yogyakarta, dan Yahya Muhaimin (1990) pada pengusaha Muslim di Bumiayu Jawa Tengah (Abdullah, 1994: 27).

Secara garis besar, ruang lingkup dalam penelitian ini membahas tentang (1) peran agama dalam mendorong kegiatan perdagangan, baik yang tampak pada perilaku ekonomi pedagang Muslim maupun pada tanggapan komunitas terhadap kegiatan perekonomian, (2) peranan agama dalam proses pembaharuan pemikiran yang dapat mengarahkan perilaku ekonomi pedagang, dan juga dapat mempengaruhi cara penduduk menerima kegiatan perekonomian dan perdagangan sebagai bagian dari kehidupan mereka.

Bagi Irwan Abdullah, penelitian pada masyarakat pedagang Muslim 
Jatinom Kabupaten Klaten-Jawa Tengah ini terdapat suatu fenomena yang sangat menarik, yaitu mengapa pedagang-pedagang Muslim di Jatinom dapat menggantikan posisi pedagang Cina dan dapat menjadi pedagang yang berhasil sampai saat ini? Menurutnya, ini merupakan fenomena semangat dagang kaum Muslim yang selalu menjadi topik hangat untuk didiskusikan bahkan sejak zaman kolonial, dan apa yang terjadi pada masyarakat pedagang Muslim Jatinom ini merupakan perkembangan yang sangat menarik, sebab pedagang pribumi di berbagai daerah selama ini bukan merupakan kelompok yang tangguh sehingga mereka tidak dapat menggeser posisi sumbersumber ekonomi dari pedagang Cina. Adapun tujuan penelitian ini adalah untuk memaparkan ciri-ciri kelompok pedagang Muslim Jatinom dan faktor-faktor yang dapat mendukung keberhasilan mereka dalam perekonomian dan perdagangan.

\section{Metode}

Untuk memandu penelitian yang dilakukan, Irwan Abdullah terlebih dahulu membicarakan dan mengkaji secara mendalam hal-hal yang bersifat teoritis melalui survei literatur sebagai pemandu dan perspektif penelitian yang dilakukan. Setelah itu ia mendiskusikan etika agama dan semangat ekonomi yang banyak dipengaruhi oleh cara berpikir Max Weber. Hal ini ia lakukan untuk melihat saluran keagamaan apa yang telah menyebabkan agama itu mempunyai daya kuat terhadap perkembangan ekonomi masyarakat (Abdullah, 1994: 20). Selanjutnya, untuk mengetahui posisi penelitian yang dilakukan, ia mengemukakan dan melihat kembali penelitian terdahulu yang pernah dilakukan oleh para peneliti sebelumnya, antara lain seperti penelitian yang dilakukan oleh Geertz (1963) di Mojokuto, penelitian Castles (1967) di Kudus, dan penelitian de Jonge (1989) di Madura, yang menunjukkan pentingnya hubungan Islam dan perdagangan. Studi Geertz (1963) tentang modernisasi ekonomi dalam hubungannya dengan pedagang Muslim di Mojokuto menunjukkan pentingnya konteks sosial-budaya pada ciri-ciri ekonomi Mojokuto. Dalam analisisnya, Geertz menghubungkan spirit berusaha pada ciri-ciri perubahan sosial di Mojokuto dengan tipe kepemimpinan ekonomi pada pedagang Muslim (Abdullah, 1994: 28). 
Mengikuti Geertz, Castles (1967) menunjukkan hubungan pengembangan usaha dengan proses pemurnian Islam di Kudus (Abdullah, 1994: 30). Sementara itu, penelitian Huub de Jonge (1989) yang dilakukan di Madura menunjukkan bahwa pembaharuan Islam telah merangsang penampilan kelompok bisnis lokal sebab terjadi perubahan pada nilainilai tradisional (Abdullah, 1994: 31). Penelitian Irwan Abdullah ini menggunakan paradigma antropologi dengan rancangan penelitian (design research) ethnography yang dalam penelitian ini secara teknis ia lakukan dengan cara berada di tengah-tengah lingkungan sosial-budaya komunitas pedagang Muslim Jatinom. Fokus penelitian ini mengkaji tentang hubungan agama dan perdagangan dalam konteks perubahan sosial-ekonomi dan sosial politik.

Untuk mengungkap kesuksesan pedagang Muslim Jatinom yang mampu menggeser pedagang Cina, ia melakukan observasi terhadap kegiatan-kegiatan mereka dan mewancarainya guna mengetahui gagasangagasan di balik perilaku yang tampak dalam kehidupan mereka sehari-hari. Dalam desain penelitian yang dibuat, ia terlcbih dahulu mendeskripsikan tiga hal, yaitu (1) kehidupan sehari-hari kota Jatinom, sebuah kota kecil di Kabupaten Klaten Jawa Tengah, (2) kegiatan ekonomi masyarakat Jatinom, dan yang ke (3) kehidupan keagamaan masyarakat Jatinom. Dalam penelitian yang dilakukan, ia juga mengunakan pendekatan historis dengan menjadikan sejarah ekonomi daerah Klaten Jawa Tengah dan pengaruhnya terhadap perkembangan perdagangan masyarakat Jatinom.

\section{Hasil Temuan}

Penelitian Irwan Abdullah ini menghasilkan beberapa temuan sebagai berikut: Pertama, keberhasilan komunitas pedagang Muslim Jatinom tidak hanya berkaitan dengan ketaatan mereka terhadap agama, akan tetapi beberapa faktor lain juga berperan cukup penting seperti semangat ekonomi dan berdagang yang mereka miliki, hubungan atau solidaritas antar sesama pedagang yang terikat dalam kelompok keagamaan, dan lain sebagainya.

Kedua, agama memiliki peran penting dalam proses pembaharuan 
pemikiran yang dapat mengarahkan perilaku ekonomi pedagang, dan juga dapat mempengaruhi cara penduduk menerima kegiatan perekonomian dan perdagangan sebagai bagian dari kehidupan mereka. Agama dalam hal ini membentuk dasar sosial-budaya yang memungkinkan keberlangasungan kegiatan ekonomi secara baik.

Ketiga, perkembangan usaha dagang selanjutnya sangat ditentukan oleh struktur politik lokal, yang dalam kenyataannya bahwa adanya kekacauan politik telah dapat menghambat dan mengganggu kegiatan dagang dan perekonomian pada umumnya. Dan, juga sebaliknya iklim politik yang baik dan kondusif dapat mendorong tumbuh-kembangnya kegiatan perekonomian dan perdagangan secara baik pula.

Keempat, perkembangan perdagangan dan berbagai kemajuan pesat yang dapat dicapai oleh pedagang Muslim Jatinom sebenarnya lebih ditentukan oleh peluang-peluang ekonomi yang muncul setelah tahun 1970 an. Demikian pula perubahan-perubahan dalam bidang pertanian di wilayah Jatinom pada tahun 1980-an telah dapat memberikan dampak paling penting dari keseluruhan tahap perkembangan ekonomi kota Jatinom. Kelima, Kesuksesan pedagang Muslim di kota sangat ditentukan oleh peningkatan kesejahteraan komunitas petani yang menjadi customer (konsumen) barangbarang pabrik yang dijual di berbagai toko di kota Jatinom.

\section{Pembahasan}

Untuk menjawab fenomena menarik pada masyarakat pedagang Muslim Jatinom yang dapat menggeser komunitas pedagang Cina, Irwan Abdullah melakukan penelitian dengan cara menelusuri tiga faktor yang saling terkait. Pertama, melihat peran agama dalam mendorong kegiatan perdagangan, baik yang tampak pada perilaku ekonomi pedagang Muslim maupun pada tanggapan komunitas terhadap kegiatan perekonomian. Dengan cara ini dimungkinkan dapat melihat dasar sosial-budaya di mana kegiatan ekonomi tersebut berlangsung.

Kedua, melihat perdagangan merupakan bagian dari sistem ekonomi yang lebih luas dan faktor penting. Oleh karena itu dalam studinya ini ia 
sangat memperhatikan perkembangan ekonomi di berbagai sektor di Jatinom dan juga perkembangan antar sektor yang saling terkait satu sama lain. Ketiga, memperhatikan perubahan sosial-keagamaan dan sosial ekonomi masyarakat pedagang Muslim Jatinom yang sebenarnya tidak dapat dipisahkan dari konteks politik lokal. Menurutnya, sruktur politik pada saat perkembangan ekonomi berlangsung dan perubahan-perubahannya sangat menentukan tumbuh-kembangnya kegiatan dagang.

Dalam menganalisis dan menjelaskan keberadaan kelompok pedagang Muslim Jatinom, ia juga melakukan dengan cara terlebih dahulu memahami proses sosial-budaya yang berlangsung dalam kehidupan mereka seharihari yang terkait dengan kehidupan di bidang perekonomian. Sedangkan terkait dengan fenomena perekonomian komunitas pedagang Muslim Jatinom, ia menggunakan konsep rasionalisasi sebagai suatu instrumen di dalam menganalisis modernisasi ekonomi ketika diterapkan oleh pedagang Muslim Jatinom (Abdullah, 1994: 11). Di samping itu, ia juga menggunakan pendekatan sejarah lisan di samping memanfaatkan bahan-bahan tertulis.

Selain daripada itu, dalam menganalisis berbagai bidang kehidupan masyarakat Jatinom, Irwan Abdullah juga melakukannya dengan cara menganalisis pengaruh Islam melalui lembaga atau organisasi Islam yang berkecimpung di bidang keagamaan dan sosial-kemasyarakatan, yaitu Muhammadiyah yang oleh kaum pedagang Muslim Jatinom dijadikan sebagai wadah dalam melakukan berbagai proses transformasi. Mengapa Muhammadiyah dijadikan sebagai wadah dalam melakukan berbagai proses transformasi? karena sejak tahun 1960 Muhammadiyah telah menjadi organisasi lslam paling penting di Jatinom (Abdullah, 1994: 84). Namun, intervensi pemerintah dalam berbagai cara pada saat itu telah menyebabkan terjadinya reorganisasi di dalam tubuh Muhammadiyah sendiri.

Selanjutnya dalam melihat sejarah ekonomi Jatinom dan pengaruhnya terhadap perkembangan perdagangan masyarakat, ia juga menjelaskan perubahan-perubahan kekuasaan ekonomi di dalam koalisi Kesunanan, Belanda, Priyayi, dan Cina. Pada masa revolusi kekuatan-kekuatan tersebur menghilang dan kekuatan masyarakat yang paling penting pada saat itu

Ulul Albab, Vol. 10, No. 1, 2009 
digantikan oleh santri dan PKI di dalam struktur pemerintahan yang baru. Namun pada tahun 1965 kekuatan PKI menghilang, dan tinggal kekuatan santrilah yang menjadi kelompok dominan dalam menggerakkan masyarakat. Pergeseran-pergeseran tersebut mempunyai pengaruh penting di dalam perkembangan ekonomi dan juga memberikan kesempatan bertumbuhnya kelompok pedagang santri.

Sementara itu untuk memaparkan ciri-ciri sosial ekonomi masyarakat Jatinom dan sekitarnya, ia melakukan dengan cara memaparkan keadaan Kabupaten Klaten sebagai daerah yang cukup subur dan daerah yang secara mendasar telah dipengaruhi oleh proses komersialisasi sejak masa penjajahan (kolonial). Struktur ekonomi di Jatinom telah mengalami diversifikasi dengan munculnya berbagai sektor kegiatan perekonomian, seperti industri-industri kecil dan perdagangan walaupun pernah terjadi aksi bumi hangus pada tahun 1948/1948 yang salah satunya dapat menyebabkan pabrik gula dan perkebunan tebu di Jatinom tidak dapat bertahan lama.

Adapun kalau penelitian ini dilihat dari perspektif keilmuan Islam, secara teoritik dapat memberikan kontribusi sebagai berikut: Pertama, memberikan sumbangan penjelasan mengenai peran agama di dalam mendorong aktivitas kehidupan manusia, yang dalam konteks penelitian ini adalah kegiatan perdagangan, baik yang tampak pada perilaku ekonomi pedagang Muslim maupun pada tanggapan komunitas terhadap kegiatan perekonomian. Sebab sebagai konsekuensi dari arus sekularisme. Menurut Sofyan S Harahap dapat meluluhlantakkan peran agama pada semua bidang publik. Domain agama didesak ke sudut, yaitu sebatas proses pengurusan lahir, nikah, dan mati. Oleh karena gelombang sekularisme in maka wilayah ekonomi yang menjadi domain kapitalisme mencoba meniadakan atau mensterilkan agama dalam setiap bidang ekonomi, terutama pada aspek kebijakan dan aturan ekonomi. Ideologi agama tidak boleh mewarnai praktik ekonomi. Ini harapan dari kapitalisme (Harahap, 2005: 17).

Kedua, peranan agama dalam proses pembaharuan pemikiran dapat mengarahkan perilaku manusia, yang dalam penelitian ini adalah perilaku ekonomi pedagang, dan juga dapat mempengaruhi cara penduduk menerima 
kegiatan perekonomian dan perdagangan sebagai bagian dari kehidupan mereka. Dalam penelitian Irwan Abdullah ini perilaku ekonomi pedagang Muslim Jatinom yang banyak memperoleh kesuksesan tersebut dipengaruhi peran agama.

Ketiga, wilayah normatif (aturan-aturan agama) apabila dilaksanakan dengan konsisten dalam praktek perekonomian akan dapat memberikan suatu keberhasilan sebagaimana yang dialami oleh pedagang Muslim Jatinom. Ini artinya, ajaran Islam sangat compatible (sejalan) dengan persoalan ekonomi. Bukan sebagaimana yang dituduhkan oleh kapitalisme bahwa agama sebagai penghambat persoalan ekonomi.

\section{Simpulan}

Dalam penelitiannya ini, Irwan Abdullah menunjukkan bahwa agama merupakan dunia simbolis yang menegaskan identitas kelompok yang dapat memperkuat rasa kebersamaan atau solidaritas antar sesama anggota yang memiliki paham yang sama. Atau dengan istilah lain, agama merupakan dasar pengelompokan sosial yang dengan ini anggota-anggota di dalamnya dapat bekerjasama dengan lancar dan harmonis. Hubungan semacam ini merupakan basis yang paling penting di dalam menggerakkan perdagangan karena sumber daya ekonomi mengalir dari satu orang ke orang lain di dalam kelompok keagamaan. Pengelompokan dagang berdasarkan agama ini sekaligus memiliki kekuatan yang besar di dalam menghadapi tekanantekanan dan berbagai ancaman atau gangguan dari luar kelompok yang dapat menghancurkan internal kelompok. Oleh karena itu, setiap orang di dalam kelompok perdagangan berusaha memelihara sifat kohesi sosial kelompok karena mempunyai fungsi langsung terhadap keberlangsungan perdagangan. 


\section{Daftar Pustaka}

Abdullah, Irwan. 1994. The Muslim Businissmen of Jatinom (Religious reform and economic modernization in a Central Javanese town. Universiteit Van Amsterdam.

Harahap, Sofyan S. 2005. Agama dan Ekonomi . Jakarta: Republika, 14 Desember.

Ulul Albab, Vol. 10, No. 1,2009 